\title{
Integrative Processes of Different Levels in Secondary Vocational Education
}

\author{
Svetlana Soloveva ${ }^{1}$, Oksana Miniakhmetova ${ }^{2}$, Anna Kivileva ${ }^{2}$, Yelena Gitman ${ }^{3,4, *}$ \\ ${ }^{1}$ Department of Pedagogy and Psychology, Solikamsk Socio-Pedagogical College named after A.P. Ramensky, Russia \\ ${ }^{2}$ Department of Pedagogy, Regional Polytechnic College, Chernushka, Russia \\ ${ }^{3}$ Faculty of Humanitarian, Perm National Research Polytechnic University, Russia \\ ${ }^{4}$ Department for Education and Psychology, Perm State Humanitarian-Pedagogical University, Russia
}

Received October 23, 2019; Revised December 3, 2019; Accepted December 4, 2019

Copyright $\bigcirc 2020$ by authors, all rights reserved. Authors agree that this article remains permanently open access under the terms of the Creative Commons Attribution License 4.0 International License

\begin{abstract}
The article analyzes the integration processes in vocational education at different levels. At the first level, the integration of education system organizations and the professional system are considered as the implementation of dual education, which allow adjusting practical training to the real production, thus ensuring the introduction of students to professional activities. The second level concerns the intraprofessional integration. The competitive activity of professional educational organizations is considered as an example. The integration of the content of natural science and professional cycle disciplines in the learning process within a certain specialty is revealed when considering the third level. The purpose of the research presented in the article is to identify the integrative processes of different levels in secondary vocational education.
\end{abstract}

Keywords Vocational Education, Educational Technologies, Competence, Integration, Dual Education, Competitive Activities, Interdisciplinary Integration, Problem-based Learning

\section{Introduction}

At the present stage, the educational system faces the challenge of training a young specialist, who is able to carry out professional activities in nonstandard conditions, is highly enterprising, and uses a creative approach when solving professional problems. Industrial production enterprises, carrying out technological innovations, need professional staff ready to master the work with updated production technologies, advanced equipment, capable of constant self-learning and self-development. Therefore, the purpose of the professional school is to prepare the graduate with not only certain knowledge, skills, and practical experience, but also able to responsibly perform their duties, as well as to adapt to changing economic conditions.

According to the National Law of December 29, 2012, No. 273-FZ "On education" [25], teaching staff should also form in students qualities, such as self-sufficiency, and cognitive activity. Obviously, using only traditional forms of education, it is impossible to fully reveal the full personal potential of students. Therefore, the challenges set before the vocational education system are more expedient to be solved by combining resources both within the educational institution and with other organizations involved in the training of young professionals, which reflects the essence of the integration processes in education.

As part of the integrative approach, education is studied as a process and the result of educational integration at different levels that allows establishing links between objects to achieve the ultimate goals [22].

\section{Literature Review}

Integration processes can be viewed at different levels. The first and the most extensive level studies the integration of vocational education and the production sector in the framework of dual education, which allows conducting practical training in accordance with the needs of real production, thus ensuring the inclusion of students in professional activities. The second level considers the intraprofessional integration. The competitive activity of professional educational organizations is considered as an example. At the third level, the integration of the content of natural science and professional cycle disciplines in the learning process is revealed with respect to a particular specialty. 
The development of production today is closely connected with the development of science and education, which is crucial in the integration of vocational education and production. Forms, in which integration of education and production can be implemented, include mentoring, training and production platforms, systems of target intensive (individual) training of students, technopolises, innovation parks, technoparks, centers of advanced training, etc. [26]. Conducting a dialogue between educational and industrial structures and taking into account the interests of employees and students is an important feature of the system, dubbed dual education [2, 17]. The dual education system is understood as an innovative type of relationship between educational organizations and partner enterprises, which results in training of graduate adapted to the production conditions. In his research Yu.N. Petrov distinguishes the following three methodological bases, on which the dual education is built: axiological, ontological (competence approach), and technological (mastering professional activity) [26].

The relevance of dual education is that due to the constant improvement of production technologies it is necessary that college graduates would be able to quickly and stress-free integrate into the production process. In this regard, a model of dual education, based on the principles of integration of theory and practice in the form of solving practice-oriented problems in the educational process and immersion in the production situation at work $[19,23,30]$, was proposed for the intermediate vocational education system. Responsibility for learning indicators falls on both the educational organization and partner enterprises [32].

As far back as in the Soviet Union, attempts were made to use dual education in the practice of the vocational school. Scientific research of S.T. Shatsky and P.P. Blonsky on the labor school formed the basis of the national system of workers training in Germany. Today, interest in the dual system is not weakening. Researchers from different countries express different points of view on the testing of the German system of dual training. Thus, A. Hoxtell justified various aspects of the implementation of the dual training idea in Germany [7]. Different approaches to the choice of this education system by students of German schools are studied in [5-7, 14]. The article [15] presents a multidimensional model for the application of educational technologies in the integration of dual vocational education. It shows the importance of reflection processes to turn specific experiences into relevant integrated knowledge. Kurtulus K., Y.E. Kadir explore the pedagogical potential of integrating vocational education and enterprises [11]. Höhns G.M. considered the issue of different educational opportunities for college students in English-speaking countries with different positions in the workplace [8]. Cantor J.A. and T.F. Remington have considered some aspects of the partnership model, which included elements of dual education, combining educational institutions, government agencies, and businesses into partnerships to upgrade technical education in the USA $[3,13]$. In Denmark, the dual education system is experiencing difficulties in providing training placements by companies to a sufficient extent [10].

It should be noted that there is also another interpretation of the dual education concept, which is training in two specialties at the same time [12]. This approach is popular in many countries, in particular in the USA. However, it is not the subject of discussion in this article.

In Russia, the return of the idea of dual education in the practice of the intermediate vocational education system is currently one of the trends in the development of professional education. The project "Training of workers who meet the requirements of high-tech industries, on the basis of dual education" [16] is aimed at training a professional graduate, adapted to the enterprises' production conditions.

The next level of integration, no less significant, but inferior to the first level in terms of implementation, is intraprofessional integration. An example of such educational integration is the competitive activity of students [24].

The competition can be described as an open form of educational integration of theory and practice, which helps to overcome the disunity of scientific knowledge in the disciplines, the formation of the overall picture of the reality in general, and the acquired profession in particular, allowing realizing creative abilities and developing communication skills.

Initially, competitions were defined as an additional form of the educational process, while they were attributed to characteristics, such as occasional application. Now the researchers propose to consider the competitive activity as an independent, special type of activity, which is characterized by a focus on self-actualization and self-determination of the student. This type of activity is a specific process of interaction of participants, which is characterized by features, such as competition and a certain social or personally significant result [31]. Competitive activity stimulates the activity of the individual, actualizes creative opportunities, cognitive activity, and allows realizing the abilities and interests of students [21]. Competition activities are characterized by traits such as voluntary participation, multifunctionality, integrity, competitiveness, creativity, dynamism, practical orientation, openness, and variability [27].

Foreign researchers note that based on the immediate activities of students, the competition provides better assimilation of educational material by increasing involvement in the learning process [1]. Self-presentation to other participants and demonstration of professional skills radically change the idea of the professional status and prestige [18], indicating the prospects of professional activity and giving the opportunity to build a trajectory of their own professional growth, giving the process of 
obtaining professional education awareness and personal interest.

At that, it should be noted that competitive activity has a number of weak sides that reduce its effectiveness. Thus, A.I. Popov points the following ones:

- the episodic nature of the competitive activities and inconsistent involvement of students in competitions;

- stressful nature of participation in competitions, which results in an inability to uncover personal potential and reduces incentives for participation;

- erroneous prioritization of participation in the competition, motivation to achieve results prevails over cognitive motivation [28].

The need for the properly formed motivation of participants is noted [9], i.e. the result of the competition should not be a fundamental factor motivating participation in the competition.

At the same time, competitive activity offers students wide didactic opportunities to deepen and expand their professional knowledge. In particular, currently, one can observe the formation of a system of national competitions for blue-collar workers under the auspices of the international nonprofit movement called WorldSkills International that provides increasing the prestige of vocational professions and the development of vocational education [22].

An example of the integration at the third level is interdisciplinary integration at the college in the course of training within a single specialty. The cross-subject integration of content [20] may serve a good example. In relation to vocational training, this is the integration of the content of natural sciences and special disciplines. In addition to increasing students' interest in the study of natural sciences, which unfortunately is currently quite weak, this kind of integration will allow solving several purely professional problems, namely:

- improving students' understanding of the essence of studied highly specialized aspects;

- facilitating the development of analytical thinking;

- making the training of students for actions in non-regular production situations more effective;

- increasing readiness for professional mobility through the expansion of natural-science fundamentals, which are the basis for many related professions.

As a means of improving the effectiveness of interdisciplinary integration, one can use problem-based learning, in particular, the problem situations of vocational orientation, used in the course of teaching natural sciences $[4,29]$.

\section{Materials and Methods}

As part of the research conducted in professional educational organizations, a retrospective analysis was carried out of the scientific literature sources and the latest research in the field of dual education, as well as the organization of professional competitive movement and the issues of problem-based learning. A comparative analysis was conducted also with regard to the normative documents database to identify the list of personal qualities indicated in the Federal Educational Standard of the intermediate vocational education, as well as additional ones indicated in professional standards of the specialties of intermediate vocational education, WorldSkills standards, as well as those required by employers. The qualitative analysis of the pedagogical activity of teachers allowed revealing the difficulties arising at the organization of educational and extracurricular processes, the choice of relevant pedagogical technologies, training methods, allowing to form these or those supraprofessional qualities in the context of dual education and competitive movement.

The analysis of professional standards made it possible to highlight personality qualities, common to many professions and specialties that should be possessed by specialists in any particular occupation. As a result of the analysis of personality qualities necessary for professional activities at enterprises, a list of qualities is defined. These qualities are, on the one hand, most valued by modern managers. However on the other hand, the formation of these qualities within the framework of the educational process is not expected. These are supraprofessional qualities, i.e. universal personality qualities, acquired through the process of professional activity, ensuring person competitiveness.

In order to study the level of integration in vocational education among teachers of secondary vocational education, the authors conducted a study, whose empirical data were based on State Budget Professional Educational Institution Solikamsk Social and Pedagogical College named after A.P. Ramensky (SBPEI SSPC) and State Autonomous Professional Educational Institution Regional Polytechnic College of Chernushka (SAPEI RPC). The experimental study involved students majored in Development of oil and gas fields, Technology of catering products, Maintenance and repair of road transport, Economics and accounting (by industries), Preschool education, Teaching in primary school, Nursing, and Medical care. The general sample of the control group (CG) and experimental group (EG) included 1,072 students enrolled in above specialties. The representative sample included 300 students of the same specialties of SBPEI SSPC and SAPEI RPC (100\% of first-year students), as well as 16 teachers and foremen of vocational training, who were part of the expert group.

At the stage of the experimental study, groups were selected in a way that would allow identifying not only the initial level of certain qualities formation but also identifying the very problem. To do this, the authors used a 
nonrandom sample type (units of the sample were selected purposefully). These samples included students studying in the context of dual education, specialties in which nonstandard situations might arise at the workplace, and students participating in competitive activities. The samples of students selected for each of the considered specialties gave qualitative results. During the ascertaining experiment, criteria and indicators were determined, which showed objective information.

Below is determined the accuracy of the matches and differences for the experimental data measured on the ordinal scale, as well as the calculation of the empirical value of the criterion $\chi_{e m p}^{2}$ by the formula (1) carried out for compared samples:

$$
\chi_{e m p}^{2}=N \cdot M \cdot \sum_{i=1}^{L} \frac{\left(\frac{n_{i}}{N}-\frac{m_{i}}{M}\right)^{2}}{n_{i}+m_{i}}
$$

The obtained calculation results are presented in Table 1.

Table 1. Empirical values of criterion $\chi_{e m p}^{2}$

\begin{tabular}{|c|c|c|c|c|}
\hline & $\begin{array}{c}\text { CG before } \\
\text { the } \\
\text { experiment }\end{array}$ & $\begin{array}{c}\text { EG before } \\
\text { the } \\
\text { experiment }\end{array}$ & $\begin{array}{c}\text { CG after } \\
\text { the } \\
\text { experiment }\end{array}$ & $\begin{array}{c}\text { EG after } \\
\text { the } \\
\text { experiment }\end{array}$ \\
\hline $\begin{array}{c}\text { CG before } \\
\text { the } \\
\text { experiment }\end{array}$ & 0 & $\mathbf{0 . 4 1}$ & 0.21 & 5.90 \\
\hline $\begin{array}{c}\text { EG before } \\
\text { the } \\
\text { experiment }\end{array}$ & 0.41 & 0 & 1.09 & 5.13 \\
\hline $\begin{array}{c}\text { CG after } \\
\text { the } \\
\text { experiment }\end{array}$ & 0.21 & 1.09 & 0 & $\mathbf{7 . 8 2}$ \\
\hline $\begin{array}{c}\text { EG after } \\
\text { the } \\
\text { experiment }\end{array}$ & 5.90 & 5.13 & 7.82 & 0 \\
\hline
\end{tabular}

Values indicated in Table 1 by bold style show the results of the comparison of the experimental and control group characteristics before and after the experiment. The value of $\chi_{e m p}^{2}$, identified when comparing the characteristics of the control group and the experimental group before the experiment, is equal to 0.41 . All other empirical values of the criterion, except for $\chi_{e m p}^{2}=7.82$, are less than a critical value.

Since $\chi_{e m p}^{2}=7.82>5.99=\chi_{0.05}^{2}$, then the significance of differences in the characteristics of the experimental and control groups after the experiment is within the range of $95 \%$.

The main research methods included observation, questioning, and conducting an experiment, which allowed making an assessment of the effectiveness of integration processes caused by the introduction of dual training, intersubjective integration, and competitive activity into the educational environment. In the course of diagnostics at the initial and intermediate stages of the experiment, standardized methods, such as tests, questionnaires, problem situations, and cases were used. The interactive voting system VOTUM, as well as statistical data processing system, was chosen as a tool for measuring the results.

\section{Results}

The study of the dual education system as an example of integration in vocational training allows asserting that in the intermediate vocational education system, dual training is aimed at involving students in educational and cognitive activities with professional orientation and regulating independent work. The dual system allows consistently alternating educational and production processes in educational institutions and in the workplace.

The advantages of integrating vocational education and enterprises include the following:

- alternating labor actions at the workplace with training at college;

- organizing the interaction with the staff to acquire professional competencies in the specialty, and familiarizing with the corporate culture of the enterprise;

- creating conditions for social adaptation, and organizing the internship when getting acquainted with new equipment and technologies;

- organizing the research environment aimed at involving students of colleges and universities, teachers, as well as enterprise employees for the implementation of innovation proposals;

- providing the possibility to obtain state support for the implementation of grants for innovation and development;

- providing advanced training to form skills and abilities.

The educational process, built on the principles of dual education is aimed at the development of professional competencies, personal qualities of graduates, which will allow them to professionally perform labor operations in production.

Below are the results of the experiment, proving the effectiveness of dual education on the formation in students of some supraprofessional qualities, i.e. qualities that are not included in the list of learning outcomes formed by the Federal Educational Standards, though required by most employers. The outcomes of the formative experiment are presented in Table 2. 
Table 2. Results of formative experiment

\begin{tabular}{|c|c|c|c|c|c|c|}
\hline \multirow{2}{*}{ Supraprofessional qualities } & \multicolumn{2}{|c|}{ High level, students/(\%) } & \multicolumn{2}{|c|}{ Average level, students/(\%) } & \multicolumn{2}{|c|}{ Low level, students/(\%) } \\
\cline { 2 - 7 } & EG & CG & EG & CG & EG & CG \\
\hline \multirow{2}{*}{ Hard work } & 12 & 8 & 56 & 50 & 32 & 42 \\
& $(12)$ & $(8.2)$ & $(56)$ & $(51.5)$ & $(32)$ & $(46.1)$ \\
\hline \multirow{2}{*}{ Self-confidence } & 18 & 11 & 68 & 66 & 14 & 20 \\
& $(18)$ & $(11.3)$ & $(68)$ & $(68)$ & $(14)$ & $(20.6)$ \\
\hline \multirow{2}{*}{ Stress resistance } & 26 & 18 & 32 & 26 & 42 & 56 \\
& $(26)$ & $(18.5)$ & $(32)$ & $(26.8)$ & $(42)$ & $(54.7)$ \\
\hline \multirow{2}{*}{ Loyalty } & 12 & 8 & 36 & 28 & 52 & 61 \\
& $(12)$ & $(8.2)$ & $(36)$ & $(28.9)$ & $(52)$ & $(62.9)$ \\
\hline \multirow{2}{*}{ Reliability } & 11 & 6 & 32 & 22 & 57 & 71 \\
& $(11)$ & $(6.2)$ & $(32)$ & $(22.7)$ & $(57)$ & $(73.2)$ \\
\hline \multirow{2}{*}{ Determination } & 12 & 4 & 34 & 14 & 54 & 79 \\
\end{tabular}

The results of the analysis suggest that dual education has pedagogical capabilities in terms of forming supraprofessional qualities of students through a combination of theory and practice in the educational organization and at the enterprise. This helps to improve the quality of practice-oriented vocational training in relevant professions.

Study of issues related to competitive activity, as an example of the next level of integration in vocational education, namely, interprofessional integration, gives reason to consider that during participation in competitions, the efficiency of mastering professional subject knowledge, as well as its scope increase. Involvement in competitions contributes to development in students of creative and professional thinking, improving their psychology of communication, professional ethics, ability to cope in nonstandard situations in professional activity, as well as the ability to solve challenging problems. In addition, the involvement of future specialists in competitive activities increases their personal potential, uncovers value system in professional activities, and forms the personality of the future professional in general.

Due to the active involvement of students in the competitive activity, there is a trend to significant reduction of the gap between requirements of employers and professional training of students, because in this case the professional skills and knowledge of graduates already meet the required level, since they have already acquired an understanding of the interprofessional communication principles and the value system accepted within the framework of a chosen profession.

Competitions, as part of the educational system, form a special interactive environment of pedagogical interaction among educators, students, and representatives of the professional environment. This circumstance changes qualitatively the nature of relations among the participants of the educational process, in particular, transforms the role of the teacher, turning an educator into a direct participant of the process.

To achieve a constructive result, the competition must meet the following requirements:

- $\quad$ should take into account the level of readiness of students (competition-related tasks should be selected based on the scope of proximal development);

- $\quad$ participants should be selected based on their abilities and training in order to achieve an approximately equal level of opportunities;

- the organizational conditions of the competition, such as time and space limits, winner criteria, rules of conduct, the composition of judges, should correspond to the level of the competition in terms of experience and qualification and must be strictly defined.

Competitions, as an accurate indicator of the mastered skills and abilities of professional activity, become an effective way of improving professional skills and creativity and are a relevant way to improve the quality of vocational education. The introduction of systematic competitive activity into the educational process will allow fully realizing the needs of students in ensuring a consistent transition to the status of a professional, as well as forming a special integrated educational environment providing optimal opportunities to improve the level of vocational education.

The content in each specific competition of a large amount of information allows strengthening intrasubject and intersubject communications, expanding the scope of information received and used that ultimately ensures the merger of educational spheres into a single educational process and ensures high results in vocational education.

The results of the ascertaining experiment are presented below. They indicate the need for competitive activity in the formation of the level of vocational education and competitiveness of students involved in intermediate vocational education, i.e. qualities that are not included in the list of learning outcomes formed by Federal Educational Standards, though are required by most employers. The results of the ascertaining experiment are presented in Table 3. 
Table 3. Results of the ascertaining experiment

\begin{tabular}{|c|c|c|c|c|}
\hline Qualities & $\begin{array}{c}\text { Zero level, } \\
\text { students/(\%) }\end{array}$ & $\begin{array}{c}\text { Low level, } \\
\text { students/(\%) }\end{array}$ & $\begin{array}{l}\text { Average level, } \\
\text { students/(\%) }\end{array}$ & $\begin{array}{l}\text { High level, } \\
\text { students/(\%) }\end{array}$ \\
\hline Professional motivation & $\begin{array}{c}7 \\
(7) \\
\end{array}$ & $\begin{array}{c}75 \\
(75) \\
\end{array}$ & $\begin{array}{c}13 \\
(13) \\
\end{array}$ & $\begin{array}{c}5 \\
(5) \\
\end{array}$ \\
\hline $\begin{array}{l}\text { Psychological and emotional stability of the individual } \\
\text { involving in the competition }\end{array}$ & $\begin{array}{c}18 \\
(18)\end{array}$ & $\begin{array}{c}60 \\
(60) \\
\end{array}$ & $\begin{array}{c}20 \\
(20)\end{array}$ & $\begin{array}{c}2 \\
(2)\end{array}$ \\
\hline Purposefulness & $\begin{array}{c}16 \\
(16)\end{array}$ & $\begin{array}{c}51 \\
(51)\end{array}$ & $\begin{array}{c}29 \\
(29)\end{array}$ & $\begin{array}{c}4 \\
(4)\end{array}$ \\
\hline Independence & $\begin{array}{c}15 \\
(15) \\
\end{array}$ & $\begin{array}{c}52 \\
(52) \\
\end{array}$ & $\begin{array}{c}28 \\
(28) \\
\end{array}$ & $\begin{array}{c}4 \\
(4) \\
\end{array}$ \\
\hline Communicativeness & $\begin{array}{c}17 \\
(17) \\
\end{array}$ & $\begin{array}{c}50 \\
(50)\end{array}$ & $\begin{array}{c}29 \\
(29)\end{array}$ & $\begin{array}{c}4 \\
(4)\end{array}$ \\
\hline Creativity & $\begin{array}{c}8 \\
(8) \\
\end{array}$ & $\begin{array}{c}54 \\
(54)\end{array}$ & $\begin{array}{c}25 \\
(25)\end{array}$ & $\begin{array}{c}13 \\
(13) \\
\end{array}$ \\
\hline
\end{tabular}

The results of the experiment allow concluding that the competitions, as an integrative educational model, expand the educational space and create motivational conditions for professional self-improvement by attracting different subjects of the educational system and professional environment.

Issues of intersubjective integration, namely, integration of the content of natural science and vocational disciplines have been discussed for a long time in the vocational education theory and practice, but they still remain relevant problems in professional training of the staff. The natural science cycle includes applied sciences that study the development and transformation of nature, namely, chemistry, biology, geography, ecology, physics, and astronomy. Practice shows that unfortunately, students of intermediate vocational education institutions treat the disciplines of the natural science cycle as being not important. They do not see the relationship between natural disciplines and those of vocational cycle. First-year students, for example, believe that the content of the natural science disciplines and special disciplines do not intersect. As a consequence, the academic performance of the students with respect to disciplines of the natural science cycle is very low. Training will be successful in case if each discipline is perceived by the student as a necessary element of his future professional activity. For example, when training cooks, a discipline, such as chemistry is necessary in order to regulate the cooking processes and control the quality of raw materials and finished products, because any cooking is associated with the transformations of substances, and hence - with chemical reactions.

Below are the experimental results proving the effectiveness of the problem-based learning on the formation of readiness in students to act in nonstandard situations, i.e. qualities, which are not taken into account in the list of learning outcomes formed by the Federal Educational Standards, but are included in the list of requirements of most employers to a qualified specialist. The results of the formative experiment are presented in Table 4. 
Table 4. Results of the formative experiment

\begin{tabular}{|c|c|c|c|c|c|c|}
\hline \multirow{2}{*}{ Qualities } & \multicolumn{2}{|c|}{ Low level, students/(\%) } & \multicolumn{2}{|c|}{ Average level students/(\%) } & \multicolumn{2}{|c|}{ High level students/(\%) } \\
\hline & EG & CG & EG & CG & EG & CG \\
\hline Quick thinking & $\begin{array}{c}22 \\
(20.7)\end{array}$ & $\begin{array}{c}14 \\
(12.9)\end{array}$ & $\begin{array}{c}65 \\
(59.9) \\
\end{array}$ & $\begin{array}{c}73 \\
(67.5) \\
\end{array}$ & $\begin{array}{c}21 \\
(19.4)\end{array}$ & $\begin{array}{c}21 \\
(19.4) \\
\end{array}$ \\
\hline Flexibility of thinking & $\begin{array}{c}65 \\
(59.9) \\
\end{array}$ & $\begin{array}{c}13 \\
(12.1)\end{array}$ & $\begin{array}{c}43 \\
(40.1)\end{array}$ & $\begin{array}{c}87 \\
(80.5)\end{array}$ & $\begin{array}{c}0 \\
(0)\end{array}$ & $\begin{array}{c}8 \\
(7.4) \\
\end{array}$ \\
\hline Profound thinking & $\begin{array}{c}91 \\
(83.9)\end{array}$ & $\begin{array}{c}52 \\
(48.1)\end{array}$ & $\begin{array}{c}17 \\
(16.1)\end{array}$ & $\begin{array}{c}48 \\
(44.5)\end{array}$ & $\begin{array}{c}0 \\
(0)\end{array}$ & $\begin{array}{c}8 \\
(7.4)\end{array}$ \\
\hline Critical thinking & $\begin{array}{c}93 \\
(86.2) \\
\end{array}$ & $\begin{array}{c}64 \\
(59.2) \\
\end{array}$ & $\begin{array}{c}15 \\
(13.8) \\
\end{array}$ & $\begin{array}{c}33 \\
(30.6) \\
\end{array}$ & $\begin{array}{c}0 \\
(0)\end{array}$ & $\begin{array}{c}11 \\
(10.2) \\
\end{array}$ \\
\hline Independent thinking & $\begin{array}{c}36 \\
(33.7) \\
\end{array}$ & $\begin{array}{c}0 \\
(0)\end{array}$ & $\begin{array}{c}68 \\
(63.1) \\
\end{array}$ & $\begin{array}{c}91 \\
(84.3)\end{array}$ & $\begin{array}{c}4 \\
(3.2) \\
\end{array}$ & $\begin{array}{c}17 \\
(15.7) \\
\end{array}$ \\
\hline Consistency in thinking & $\begin{array}{c}31 \\
(29)\end{array}$ & $\begin{array}{c}31 \\
(29)\end{array}$ & $\begin{array}{c}77 \\
(71)\end{array}$ & $\begin{array}{c}77 \\
(71)\end{array}$ & $\begin{array}{c}0 \\
(0)\end{array}$ & $\begin{array}{c}0 \\
(0)\end{array}$ \\
\hline
\end{tabular}

The analysis of the presented results allowed drawing a conclusion about the beneficial effect of problem-based learning in all its diversity, as well as the integration of the content of professional and natural science disciplines on the formation of the readiness in students to work in the nonstandard situations. Thus, the goal of experimental work has been achieved.

Integration of the disciplines of the natural science and professional cycles allows establishing interdisciplinary connections, forming the motivation to study natural science disciplines, expanding understanding of students that the laws of natural science disciplines will allow them to easily navigate in the disciplines of the professional cycle, because natural science knowledge lays the basis of any professional discipline or interdisciplinary course.

\section{Conclusions}

Based on the study of the integration processes in the secondary vocational education system depending on the integration level, the following conclusions have been drawn:

1. Dual education helps to improve the quality of education while taking into account the requirements of both consumers and customers. This contributes to the following:

- optimization of the learning process through the intensification of practical training;

- coordination and adaptation of educational and production activities of educational organizations to the conditions of production at enterprises;

- technological nature of training, contributing to the development of practical skills, and the formation of professional competencies.

2. Systematization of competitive activity contributes to the formation of an integrated educational environment that creates optimal opportunities for improving the level of vocational education.
3. The interdisciplinary integration results are systematic knowledge, as well as generalization of skills when solving practice-oriented or problem-based issues.

The materials of the article can be used by teachers of intermediate vocational education institutions, involved in the training quality management of specialists of secondary professional level, practicing teachers - for the development of targeted activities (competitions, Olympiads, dual education in the form of excursions, competitive platforms for WorldSkills, etc.) when training specialists of sufficiently high level. Discussion of the present research outcomes among teachers shows the need for further study of this issue in the professional educational environment.

\section{Acknowledgements}

The authors express gratitude to anonymous reviewers for careful reading of the article and valuable comments that contributed to its significant improvement.

\section{REFERENCES}

[1] M. Akpinar, C. Campo, E. Eryarsoy. Learning effects of an international group com-petition project. Innovations in Education and Teaching International, Vol. 52, No. 2, 2015. Online available fromhttp://earsiv.sehir.edu.tr:8080/xmlui/ bitstream/handle/11498/28748/000120035010.pdf?sequenc e.

[2] Ausbildung \& Beruf. Rechte und Pflichten während der Berufsausbildung. Bonn, Berlin, 2007 (aktualisierter Nachdruck 2008).

[3] J. A. Cantor. Apprenticeships link community-technical colleges and business and industry for workforce training. Community College Journal of Research and Practice, Vol. 19, No. 1, 47-71, 1995. 
[4] W. R. R. Dueñas, A. M. R. Rincón. Interdisciplinary work as a pedagogical innovation for biomedical engineering and health science students. IFMBE Proceedings, Vol. 68, No. 1, 855-858, 2019. World Congress on Medical Physics and Biomedical Engineering, WC 2018; Prague; Czech Republic; 3 June 2018 - 8 June 2018.

[5] Duale Berufsausbildung sichtbar gemacht. Erste Auflage, Redaktionsschluss: Juli 2015. Online available from www.bmbf.de/pub/Duale_Berufsausbildung_sichtbar_gem acht_Broschuere.pdf.

[6] Ph. Gonon. Quality Doubts as a Driver for Vocational Education and Training (VET) Reforms - Switzerland's Way to a Highly Regarded Apprenticeship System. Pilz, Matthias (Ed.): Vocational Education and Training in Times of Economic Crisis. Dodrecht et al.: Springer, 341-354, 2017.

[7] A. Hoxtell. Reasons of students and apprentices to choose a training company in the dual system. Journal of Vocational Education and Training, 1-19, 27 April 2018.

[8] G. M. Höhns. Pedagogic practice in company learning: the relevance of discourse. Journal of Vocational Education and Training, Vol. 70, No. 2, 3, 313-333, April 2018.

[9] D. W. Johnson, R. T. Johnson. The impact of cooperative, competitive, and individualistic learning environments on achievement, 2013. Online available from https://www.res earchgate.net/publication/260596923 Johnson D W John son_R_T_2013_The_impact_of_cooperative_competitive and individualistic learning environments on achieveme nt_In_J_Hattie_E_Ānderman_Eds_International_handboo $\mathrm{k}$ of student achievement $3 \overline{7} 2$.

[10] I.A. Juul, C.H. Jørgensen. Challenges for the dual system and occupational self-governance in Denmark. Journal of Vocational Education and Training, Vol. 63, No. 3, 289-303, September 2011.

[11] K. Kurtulus, Y. E. Kadir. Determining Factors Hindering University-Industry Collaboration: An Analysis from the Perspective of Academicians in the Context of Entrepreneurial Science Paradigm. International Journal of Social Inquiry, Vol. 4, No. 1, 185-213, 2011.

[12] J. Pretlow. Dual Enrollment, Community Colleges, and Baccalaureate Degree Attainment. Community College Journal of Research and Practice, Vol. 38, No. 2-3, 264-269, 2014.

[13] T. F. Remington. Public-private partnerships in TVET: adapting the dual system in the United States. Journal of Vocational Education and Training, 1-26, 20 June 2018.

[14] T. Healy. Learning by doing - the importance of apprenticeship learning in Northern Ireland [Digital

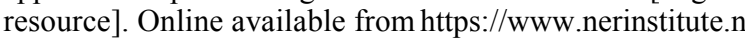
et/blog/2014/10/02/learning-by-doing-the-importance-of-a pprenticeship/.

[15] B. A. Schwendimann, A. A. P. Cattaneo, J.C. Dehler Zufferey, J.-L. Gurtner, M.D. Bétrancourt, P. Dillenbourg. The 'Erfahrraum': a pedagogical model for designing educational technologies in dual vocational systems. Journal of Vocational Education and Training, Vol. 67, No. 3, 367-396, 3 July 2015.

[16] Agency for strategic initiatives. System project. Training of workers who meet the requirements of high-tech industries, on the basis of dual education. Online available from http://asi.ru/projects/7267/ (accessed 06.06.2018).

[17] S. V. Baranova. Dual education: opportunities of realization of conditions of profile training. Actual aspects of fundamental and applied researches: collection of scientific works, No. 3, 119-125, 2016

[18] N. D. Berman. On the issue of professional self-determination of students. Modern studies of social problems, 2018. Online available from: https://cyberlenink a.ru/article/n/k-voprosu-o-professionalnom-samoopredelen ii-studentov

[19] N. V. Grigorieva, L. A. Mokretsova, N. A. Shvets. Technology of training in the conditions of dual training. Vestnik TSPU, Vol. 1, No. 190, 2018. Online available from https://cyberleninka.ru/article/n/tehnologiya-podgoto vki-spetsialistov-v-usloviyah-dualnogo-obucheniya (date accessed: 31.01.2019).

[20] E. V. Krivolapova. Realization of interdisciplinary connections in the process of teaching chemistry to students of technical direction. Young scientist, Vol. 21, No. 1, 38-40, 2017.

[21] A.N. Ksenofontova, E.P. Tabakova, E. P. Pedagogical conditions of self-determination of high school students in competitive activity. Bulletin of the Orenburg state University, 2006. Online available fromhttps://cyberlenink a.ru/article/n/pedagogicheskie-usloviya-samoopredeleniyastarsheklassnikov-v-konkursnoy-deyatelnosti.

[22] K. A. Lukin, I. A. Kryukov, N. I. Stepanova, G. M. Snesarev. Competitive activities of students, act as an effective way to increase interest in get a profession. International journal of applied and fundamental research, Vol. 5, No. 1, 132-136, 2017. Online available from https://applied-research.ru/ru/article/view?id=11557

[23] N. N. Matveev. Innovative management of technical schools in the conditions of dual education: dis. ... kan. PED. sciences'. Velikiy Novgorod, 2018. Online available from http://www.novsu.ru/file/1469215 $\square$ (date accessed: 12.01 .20 19).

[24] V. L. Matrosov, N. Yu. Borisova, D. A. Melnikov, L. M. Aunapu. Competitions of professional skill as a form of teaching students interactive forms of interaction on the basis of educational integration. Science and school, 2012. Online available from https://cyberleninka.ru/article/n/kon kursy-professionalnogo-masterstva-kak-forma-obucheniya -studentov-interaktivnym-formam-vzaimodeystviya-na-osn ove-obrazovatelnoy.

[25] On education in the Russian Federation: National Law of December 29, 2012, No. 273-FZ adopted by the State Duma on December 21, 2012; amended on 25 December 2018, collected legislation of the Russian Federation, 31.12.2012, № 53 (part 1). St. 7598 .

[26] Yu. N. Petrov, V. V. Zemlyansky. The dual system of continuing professional education at College. Vestnik of FGOU VPO MGAU, No. 3, 34-37, 2010.

[27] O. A. Petrukhina, I. V. Fetter. Features of pedagogical interaction in competitive activity of students of pedagogical high school. Bulletin of Orenburg state pedagogical University, Vol. 1, No. 17, 2016. Online 
available from http://vestospu.ru/archive/2016/articles/28 17_2016.pdf

[28] A. I. Popov, E. A. Levchenko. Olympiad movement in mathematics as a way to improve the independent work of Junior students. Bulletin of Tomsk state pedagogical University, 2013. Online available fromhttps://cyberlenink a.ru/article/n/olimpiadnoe-dvizhenie-po-matematike-kak-s posob-sovershenstvovaniya-samostoyatelnoy-raboty-stude ntov-mladshih-kursov.

[29] E. V. Razova, N. Bushmeleva. Improving the quality of education through the integration of subjects. Scientific and methodological electronic journal "Concept", Vol. 6, 46-50, 2015.

[30] L. V. Sidakova. The essence and the main features of the dual model of training. Education and upbringing, Vol. 2, 62-64, 2016. Online available from https://moluch.ru/th/4/ archive/29/803/ (accessed: 25.01.2019).

[31] N. S. Cold. Competitions and Olympiads as a means of formation of creative culture of students in extracurricular activities in a foreign language at the University. Bulletin of Tomsk state pedagogical University, 2016. Online available fromhttps://cyberleninka.ru/article/n/konkursy-i-olimpiady -kak-sredstvo-formirovaniya-tvorcheskoy-kultury-studento v-vo-vneauditornoy-deyatelnosti-po-inostrannomu-yazyku $-\mathrm{V}$.

[32] M. A. Shuvalova. Formation of professional competences of technicians of high-tech industries in the conditions of dual training. Vestnik KSPU im. V. P. Astafiev, Vol. 2 No. 32, 2015. Online available from https://cyberleninka.ru/article/ $\mathrm{n}$ /formirovanie-professionalnyh-kompetentsiy-tehnikov-vy sokotehnologichnyh-otrasley-promyshlennosti-v-usloviyah -dualnogo-obucheniya (date accessed: 25.03.2016). 